\title{
Grundtvig-Selskabet af 8. september 1947
}

\section{Årsberetning 2012}

\author{
Ved Peter Balslev-Clausen
}

Grundtvig-Selskabets årsmøde 2012 blev afholdt lørdag den 10. november i Vartov, Farvergade 27, København, med Lars Thorkild Bjørn som dirigent. Ved de ordinære valg blev Peter Balslev-Clausen genvalgt til styrelsen. Det blev besluttet at lade den vakante styrelsesplads efter Ulrik Overgaard stå åben indtil næste årsmøde. Johnny Kondrup blev nyvalgt til repræsentantskabet. I forbindelse med årsmødet blev der afholdt et seminar, hvis emne var Grundtvigs Verdenskrønike 1812. Ole Vind talte om verdenskrøniken som "En ny historiefilosofi", Flemming Lundgreen-Nielsen om verdenskrøniken som en verdenslitteraturhistorie og Kim Arne Pedersen om modtagelsen af verdenskrøniken.

Efter årsmødet konstituerede styrelsen sig med Peter BalslevClausen som formand, Flemming Lundgreen-Nielsen som næstformand og ansvarshavende redaktør, Erik Jakob Petersen som kasserer og Anders Holm som sekretær og medlem af redaktionen. Styrelsen har siden sidste årsmøde holdt møder 18. januar, 10. april, 10. maj, 19. juni, 14. august og 4. oktober. Alle møder blev afholdt i Vartov, København. Styrelsen har siden sidste årsmøde udnævnt den mangeårige medredaktør for Grundtvig-Studier, S. A. J. Bradley, til æresmedlem af selskabet.

Grundtvig-Studier 2012, der blev redigeret af Flemming LundgreenNielsen (ansvarshavende redaktør) og Anders Holm, indeholdt artikler af Søren Jensen (Jakob Balling in memoriam), Bent Christensen (Fra Hamann til Fasc. 209.10. Om Grundtvigs forhold til Johan Georg Hamann og dennes samtidige), Troels Nørager (Præsten og Loke. Grundtvigs apologetiske dialog i "Om Christendommens Sandhed"), Henrik Yde ("Til Nordmænd om en Norsk Høi-Skole" 1837. En indledning), Hans Raun Iversen (N. F. S. Grundtvigs trinitariske folkekirketeologi i nordisk kontekst), Ole Nyborg (N. F. S. Grundtvig og naturalismen), Jenny Rebecca Rytting (An English Translation of "Forunderligt at sige"), Clay Warren (An American Perspective of the Impact of N. F. S. Grundtvig's Educational Ideas), K. E. Bugge (The International Dissemination of Grundtvig's Educational Ideas. I: Motivation and Interpretation) og Aage Jørgensen (Grundtviglitteratur 2009-2012: En bibliografi), hvortil kommer en fyldig anmeldelse ved Therese Bering Solten af Svend Bjerg og Søren Holst: Den gyldne Harpe.

Satsproduktionen på Grundtvig-Studier 2013 er i gang, idet der dog afventes et sidste bestilt bidrag, før det endelige sidetal kan opgøres, og redigeringen dermed kan afsluttes. 
I henhold til samarbejdsaftalen af 1. juni 2009 udgives GrundtvigStudier sammen med Grundtvig Centeret, der i det forløbne år har bistået Grundtvig-Selskabet med råd og dåd i forbindelse med den digitalisering af alle hidtidige årgange af Grundtvig-Studier, der betyder, at årbogens mange artikler snart vil være elektronisk til rådighed for læge som lærde Grundtvig-interesserede.

Redaktionen af samlebindet om Dansk Ravne-Galder er endnu ikke afsluttet. Om alt går vel, vil udgivelsen finde sted til næste år.

I lighed med tidligere år skal der også ved dette årsmøde lyde en tak til dem, der i årets løb har bistået Grundtvig-Selskabet i dets virke. Først og fremmest skal takken rettes til Grundtvigsk Forum, der siden sidste årsmøde har fået ny formand, Niels Henrik Arendt (der har afløst Thorsten Johannesen ved Grundtvigsk Forums årsmøde i oktober i år), sekretariatsleder Joachim Juel Vædele (der siden sidste årsmøde har afløst Hans Grishauge) og sekretær Kirsten Grishauge. En tak skal også rettes til selskabets mange medlemmer i Danmark, Norge og resten af verden for deres usvækkede interesse for og støtte til Grundtvig-Selskabets arbejde for "at fremme studiet af N. F. S. Grundtvig, hans virke og hans stilling i åndslivet i og uden for Danmark." 